\title{
Genistein does not Inhibit TGF-ק1-Induced Conversion of Human Dermal Fibroblasts to Myofibroblasts
}

\author{
Miriam KAŇUCHOVÁ ${ }^{1^{*}}$, Lukáš URBAN ${ }^{1,2^{*}}$, Nikola MELEGOVÁ ${ }^{1}$, Matúš ČOMA ${ }^{1,2}$, \\ Barbora DVOŘÁNKOVÁ ${ }^{3,4}$, Karel SMETANA JR. ${ }^{3,4}$, Peter GÁL ${ }^{1,2,5}$ \\ * These authors contributed equally to this work.
}

${ }^{1}$ Department of Pharmacology, Pavol Jozef Šafárik University, Košice, Slovak Republic,

${ }^{2}$ Department of Biomedical Research, East-Slovak Institute of Cardiovascular Diseases, Košice, Slovak Republic, ${ }^{3}$ Institute of Anatomy, First Faculty of Medicine, Charles University, Prague, Czech Republic, ${ }^{4}$ BIOCEV, First Faculty of Medicine, Charles University, Vestec, Czech Republic, ${ }^{5}$ Prague Burn Centre, Third Faculty of Medicine, Charles University and University Hospital Kralovske Vinohrady, Prague, Czech Republic

Received February 23, 2021

Accepted May 20, 2021

Epub Ahead of Print September 10, 2021

\begin{abstract}
Summary
Transforming growth factor beta 1 (TGF- $\beta 1$ ) is a pro-fibrotic cytokine with a key role in wound repair and regeneration, including induction of fibroblast-to-myofibroblast transition. Genistein is a naturally occurring selective estrogen receptor modulator with promising anti-fibrotic properties. In the present study we aimed to investigate whether genistein modulates TGF- $\beta 1$ (canonical and non-canonical) signaling in normal dermal fibroblasts at the protein level (Western blot and immunofluorescence). We demonstrated that TGF- $\beta 1$ induces the myofibroblast-like phenotype in the studied fibroblast signaling via canonical (SMAD) and non-canonical (AKT, ERK1/2, ROCK) pathways. Genistein induced only ERK1/2 expression, whereas the combination of TGF- $\beta 1$ and genistein attenuated the ERK1/2 and ROCK signaling. Of note, the other studied pathways remained almost unaffected. From this point of view, genistein does not impair conversion of normal fibroblasts to myofibroblast-like cells.
\end{abstract}

\section{Key words}

Wound healing - Selective estrogen receptor modulator • Phytoestrogen

\section{Corresponding author}

P. Gál, Department of Pharmacology, MediPark and East-Slovak
Institute of Cardiovascular Diseases, Trieda SNP 1, 04011 Košice, Slovak Republic. Fax: +421 55789 1613. E-mail: galovci@yahoo.com or pgal@vusch.sk

Ageing is associated with deterioration in physical condition (Hill et al. 2020) also related to estrogen deprivation during menopause. Estrogens have been shown to modulate a variety of biological processes (Herichova et al. 2019, Herichova et al. 2020) including wound healing (Ashcroft et al. 1997). In particular the age-related reduced rate of wound healing is associated with improved quality of scarring and reduced levels of transforming growth factor beta 1 (TGF- $\beta 1$ ). TGF- $\beta 1$ is a pro-fibrotic cytokine with a key role in wound repair and regeneration (Klass et al. 2009). TGF- $\beta 1$ is transiently up-regulated in normal skin wounds, whereas its ability to induce fibroblast-to-myofibroblast conversion is crucial for the wound closure (Lichtman et al. 2016), even though myofibroblasts never represent the dominating cell population in contracting human wounds (Berry et al. 1998). Characteristically, these cells express $\alpha$-smooth muscle actin ( $\alpha$-SMA) and secrete a variety of regulatory/signaling molecules, and they also actively participate in production and organization of the extracellular matrix (ECM) (Pakshir et al. 2020). TGF- $\beta 1$

PHYSIOLOGICAL RESEARCH • ISSN 1802-9973 (online) - an open access article under the CC BY-NC-ND 4.0 license (c) 2021 Institute of Physiology of the Czech Academy of Sciences, Prague, Czech Republic Fax +420 241062 164, e-mail: physres@fgu.cas.cz, www.biomed.cas.cz/physiolres 
signaling occurs either via canonical (SMAD) or noncanonical (phosphoinositide-3-kinase (PI3K/AKT), mitogen activated protein kinases (MAPK/ERK1/2), Rho GTPase (ROCK) and p53) pathways (Shi et al. 2020) with the presence of further possible cross-talks (Derynck et al. 2003, Zhang 2003).

It has been shown that genistein (GEN), a naturally occurring isoflavone and selective estrogen receptor modulator (Diel et al. 2001), may act as an antifibrotic agent (Andugulapati et al. 2020, Ning et al. 2020) and effective skin wound healing modulator (Emmerson et al. 2010, Marini et al. 2010). Estrogen receptor (ER) signaling attenuates TGF- $\beta 1$-induced activation of Sma and MAD-related protein 3 (SMAD3), whereas TGF- $\beta 1$ signaling increases ER-mediated transcription activity (Matsuda et al. 2001). Since myofibroblasts persist in chronic inflammatory and fibroproliferative diseases, they contribute to the disease progress (Cannito et al. 2017). Thus, we were interested to answer the question whether genistein as a potential anti-fibrotic molecule also modulates the TGF- $\beta 1$-induced fibroblast-tomyofibroblast conversion in cells isolated from the normal healthy skin.

HDFs were isolated (Dvorankova et al. 2019) from two healthy donors with the informed consent of the patient and Ethical Committee of the Third Faculty of Medicine, Charles University in Prague approval following the Helsinki declaration. Briefly, small pieces of residual skin specimens were enzymatically treated with $0.25 \%$ trypsin (Sigma-Aldrich, St. Louis, MO, USA) at $37^{\circ} \mathrm{C}$ for $30 \mathrm{~min}$. Epidermis was peeled off and dermis specimens were cut into small pieces and seeded on cultivation dishes containing Dulbecco's medium (DMEM) with $10 \%$ fetal bovine serum (FBS) and antibiotics (all from Biochrom, Berlin, Germany) at $37{ }^{\circ} \mathrm{C}$ and $5 \% \quad \mathrm{CO}_{2} / 95 \%$ air atmosphere. After 18/15 (donor 1/2) days, migrating cells were collected and further expanded by culturing. For the experiment passage 10 was used.

HDFs were seeded on Petri dishes/cover slips at the density of 3,000 cells $/ \mathrm{cm}^{2}$ in standard cultivation medium. Next day, the medium was changed and cells were cultivated for nine days (medium was changed on day 3 and 7) in the presence $(10,100$ and $1000 \mathrm{nM} / \mathrm{ml})$ or absence (control) of genistein (Tocris Bioscience, Abingdon, UK). TGF- $\beta 1$ (PeproTech, London, UK) at a final concentration of $30 \mathrm{ng} / \mathrm{ml}$ was used as positive control (Brenmoehl et al. 2009). To assess the genistein effect on TGF- $\beta 1$-mediated myofibroblast differentiation, cells were treated with medium containing a combination of TGF- $\beta 1$ and genistein.

Cells cultivated on Petri dishes were scratched and collected in Laemmli lysis buffer $(0.1 \mathrm{M}$ Tris/HCl (pH 6.8), $20 \%$ glycerol, $10 \%$ SDS (sodium dodecyl sulfate)) containing protease and phosphatase inhibitors (Sigma-Aldrich). Afterwards, samples were sonicated (QSonica, Newtown, CT, USA, $40 \%$ amplitude, $15 \mathrm{~s}$ ) to ensure complete cell lysis. Before loading into SDS-PAGE gel $\left(10 \%\right.$ Bis-Tris), samples were shortly boiled $\left(95^{\circ} \mathrm{C}\right.$, $5 \mathrm{~min}$ ). Following separation, proteins were dry blotted to PVDF membrane using the iBlot 2 (Thermo Fisher Scientific) system and blocked in $5 \%$ NFDM/BSA (nonfat dry milk/bovine serum albumin) dissolved in TBS (trisbuffered saline) with $0.1 \%$ Tween 20 (Sigma-Aldrich) at room temperature. After overnight incubation at $4{ }^{\circ} \mathrm{C}$ with primary antibody, membranes were incubated with appropriate HRP-conjugated secondary antibodies for $1 \mathrm{~h}$ at room temperature. Protein bands were detected as chemiluminescent signal from ECL (SuperSignal West Pico PLUS chemiluminescent Substrate, Thermo Fisher Scientific) acquired at MF-ChemiBis 2.0 (DNR Bio Imaging Systems, Israel). $\beta$-Actin was used to verify equal sample loading. The list of antibodies applied in Western blotting is shown in Table 1.

Cells cultivated on cover slips were shortly fixed ( $2 \%$ buffered paraformaldehyde, $\mathrm{pH} \sim 7.2,5 \mathrm{~min}$ ) and washed with phosphate-buffered saline (PBS). Afterwards, cell membranes were permeabilized by Triton X-100 (Sigma-Aldrich) and blocked by porcine serum albumin (DAKO, Glostrup, Denmark). Following $1 \mathrm{~h}$ incubation at room temperature with primary antibody, samples were washed and incubated with appropriate secondary antibody. Cell nuclei were stained by 4', 6-diamidino-2phenylindole (DAPI; Sigma-Aldrich). All coverslips were mounted in Vectashield (Vector Laboratories, Burlingame, CA, USA) and investigated by a fluorescence microscope (Eclipse Ni-E, Nikon, Tokyo, Japan) equipped with filter cubes for fluorescein isothiocyanate (FITC), tetramethylrhodamine isothiocya-nate (TRITC), DAPI, digital camera C11440 ORCA-flash 4.0 (Hamamatsu, Hamamatsu City, Japan), and NIS-Elements software (Nikon). The list of antibodies used for the immunofluorescent analysis is shown in Table 1.

The capability of HDFs to differentiate into myofibroblasts following TGF- $\beta 1$ exposure was affirmed by increased $\alpha$-SMA and fibronectin expressions (Fig. 1A) and further confirmed by immunofluorescence (Fig. 1B). 
Table 1. Antibodies used for Western blot and immunofluorescence.

\begin{tabular}{|c|c|c|c|c|c|c|c|c|}
\hline \multicolumn{9}{|c|}{ Antibodies used for Western blot } \\
\hline \multicolumn{2}{|c|}{ Primary Antibody } & Abbreviation & \multicolumn{2}{|c|}{ Host } & Isotype & Clonality & \multicolumn{2}{|c|}{ Produced by } \\
\hline \multicolumn{2}{|c|}{$\alpha$-Smooth muscle actin } & $\alpha$-SMA & \multicolumn{2}{|c|}{ Rabbit } & $\operatorname{IgG}$ & Monoclonal & \multicolumn{2}{|c|}{ CST, Danvers, MA, USA } \\
\hline \multicolumn{2}{|c|}{ Fibronectin } & Fibr & \multicolumn{2}{|c|}{ Rabbit } & $\operatorname{IgG}$ & Monoclonal & \multicolumn{2}{|c|}{ Abcam, Cambridge, UK } \\
\hline \multicolumn{2}{|c|}{ Phospho-ERK1/2 } & pERK1/2 & \multicolumn{2}{|c|}{ Rabbit } & & Polyclonal & \multicolumn{2}{|c|}{ CST, Danvers, MA, USA } \\
\hline \multicolumn{2}{|c|}{ Phospho-AKT } & pAKT & \multicolumn{2}{|c|}{ Rabbit } & $\operatorname{IgG}$ & Monoclonal & \multicolumn{2}{|c|}{ CST, Danvers, MA, USA } \\
\hline \multicolumn{2}{|c|}{ Phospho-SMAD3 } & pSMAD3 & \multicolumn{2}{|c|}{ Rabbit } & $\operatorname{IgG}$ & Monoclonal & \multicolumn{2}{|c|}{ Abcam, Cambridge, UK } \\
\hline ERK1/2 & & ERK1/2 & \multicolumn{2}{|c|}{ Rabbit } & $\operatorname{IgG}$ & Monoclonal & \multicolumn{2}{|c|}{ CST, Danvers, MA, USA } \\
\hline$S M A D 3$ & & SMAD3 & \multicolumn{2}{|c|}{ Rabbit } & $\mathrm{IgG}$ & Monoclonal & \multicolumn{2}{|c|}{ CST, Danvers, MA, USA } \\
\hline$A K T$ & & AKT & \multicolumn{2}{|c|}{ Rabbit } & & Polyclonal & \multicolumn{2}{|c|}{ CST, Danvers, MA, USA } \\
\hline$\beta$-Actin & & $\beta$-actin & \multicolumn{2}{|c|}{ Rabbit } & $\operatorname{IgG}$ & Monoclonal & CST, Danvers, & A, USA \\
\hline $\begin{array}{l}\text { D-Glyceraldel } \\
\text { 3-phosphate }\end{array}$ & & PH & Rat & & $\operatorname{IgG}$ & Monoclonal & CST, Danvers, & A, USA \\
\hline Secondary Ar & ibody & & Hos & & & Isotype & Produce & \\
\hline Anti-rabbit, $H$ & D-linked & & goat & & & $\operatorname{IgG}$ & CST, Danvers, & A, USA \\
\hline Antibodies u & for immunofl & rescence & & & & & & \\
\hline $\begin{array}{l}\text { Primary } \\
\text { Antibody }\end{array}$ & Abbreviation & Hos & & Pro & duced by & $\begin{array}{l}\text { Secondary } \\
\text { Antibody }\end{array}$ & Produced by & Channel \\
\hline $\begin{array}{l}\alpha \text {-Smooth } \\
\text { muscle actin }\end{array}$ & $\alpha$-SMA & $\begin{array}{r}\text { Mou } \\
\text { monoc }\end{array}$ & & $\begin{array}{c}\text { Dak } \\
\text { on, }\end{array}$ & $\begin{array}{l}\text { Deytomati } \\
\text { Denmark }\end{array}$ & $\begin{array}{l}\text { Goat anti- } \\
\text { mouse }\end{array}$ & $\begin{array}{c}\text { Sigma-Aldrich, } \\
\text { St. Louis, MO, } \\
\text { USA }\end{array}$ & $\begin{array}{l}\text { TRITC- } \\
\text { red }\end{array}$ \\
\hline Fibronectin & Fibr & $\begin{array}{r}\text { Rabt } \\
\text { polycl }\end{array}$ & & $\begin{array}{l}\text { Dak } \\
\text { on, }\end{array}$ & $\begin{array}{l}\text { Cytomati } \\
\text { Denmark }\end{array}$ & $\begin{array}{l}\text { Goat anti- } \\
\text { rabbit }\end{array}$ & $\begin{array}{l}\text { Sigma-Aldrich, } \\
\text { St. Louis, MO, } \\
\text { USA }\end{array}$ & $\begin{array}{l}\text { FITC- } \\
\text { green }\end{array}$ \\
\hline
\end{tabular}

In detail, clearly visible SMA-positive stress fibers were present in TGF- $\beta 1$ treated groups. Moreover, TGF- $\beta 1$ treatment induced deposition of a more prominent fibronectin-rich ECM scaffold. In contrast, WB showed that GEN affects neither $\alpha$-SMA nor fibronectin expressions; thus, it did not induce fibroblast-tomyofibroblast differentiation. Instead ECM deposition was rather inhibited by GEN. Interestingly, this effect persisted also in the presence of TGF- $\beta 1$.

WB analysis (Fig. 1A) further revealed that TGF- $\beta 1$ activated each studied signaling pathway to a different level. In particular, pSMAD and pERK1/2 were affected the most. On the other hand, GEN induced only pERK1/2 expression. Interestingly, the combination of GEN and TGF- $\beta 1$ attenuated the TGF- $\beta 1$-induced pERK1/2 and ROCK1 protein levels. Of note, GEN slightly decreased MLCK expression, but the effect was abolished in the presence of TGF- $\beta 1$.

In the present study, we demonstrated that
TGF- $\beta 1$ induces the myofibroblast-like phenotype in the studied primary culture of HDFs. It has been previously shown that GEN inhibits secretion of ECM proteins and expression of TGF- $\beta 1$ at both protein and mRNA levels in renal mesangial cells (Yuan et al. 2009) and keloid fibroblasts (Jurzak et al. 2014). However, the GEN ability to decrease TGF- $\beta 1$-induced $\alpha$-SMA expression was not observed in the present study. In contrast to a previously shown inhibitory effect of GEN on MAPK signaling in keloid fibroblasts (Cao et al. 2008), we observed induction of the MAPK signaling pathway (phosphorylation of ERK1/2) in HDFs. Although we showed that TGF- $\beta 1$ induced both canonical (SMAD) and non-canonical (MAPK, AKT, ROCK) signaling, a combination of GEN and TGF- $\beta 1$ attenuated the ERK1/2 and ROCK signaling in HDFs, whereas the other studied pathways remained almost unaffected. From this point of view, GEN should not impair the wound contraction induced by TGF- $\beta 1$ in normal/healthy subjects. 
A

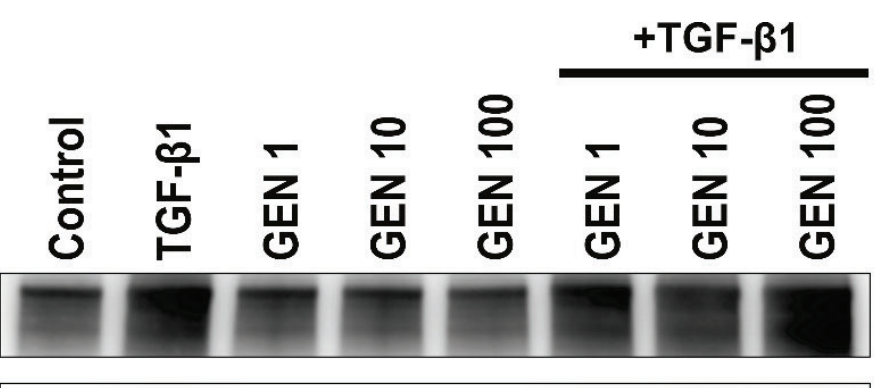

Fibronectin
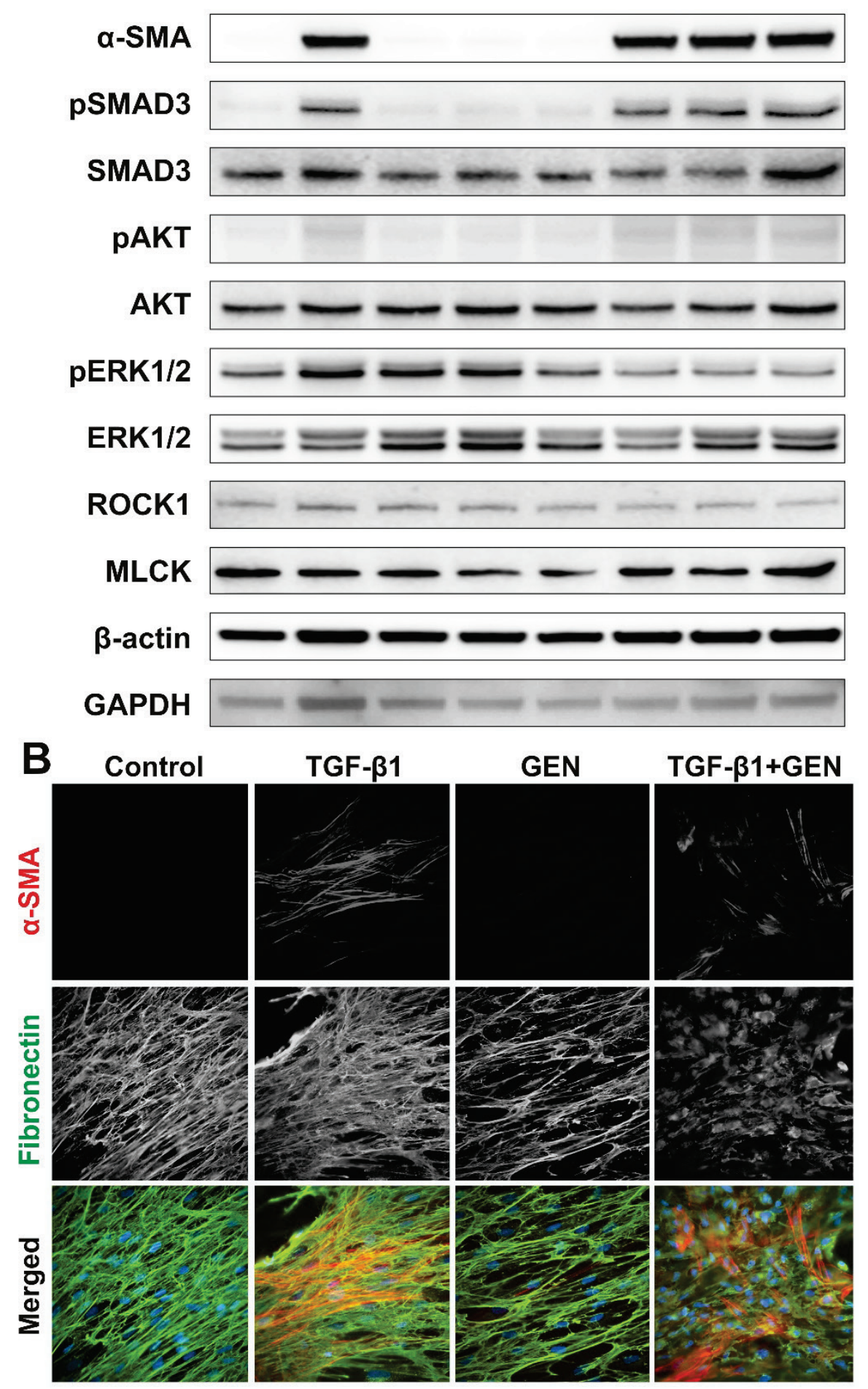

Fig. 1. (A) Western blot analysis of human dermal fibroblasts exposed to genistein (GEN - 1, 10 and $100 \mathrm{nM}$ ) and/or TGF- $\beta 1$ $(30 \mathrm{ng} / \mathrm{m}) ;$ (B) Immunofluorescence analysis of human dermal fibroblasts (HDF) exposed to genistein (GEN - $100 \mathrm{nM}$ ) and/or TGF- $\beta 1$ (30 ng/ml); a-SMA - alpha-smooth muscle actin (red signal); Fibr - fibronectin (green signal); nuclei were labeled with DAPI (blue signal) (magnification 600x). 
Even though the exact mechanism is still not fully understood, several cytokines have been identified (IL-6, IL-8, IL-10, and TGF- $\beta$ ) to play major regulatory roles in the pathophysiology of keloids and hypertrophic scar development (Berman et al. 2017). In particular, genistein at high concentration $(100 \mu \mathrm{M})$ arrested hypertrophic fibroblasts proliferation and decreased collagen deposition, whereas normal skin fibroblasts remained rather unaffected (Cao et al. 2009). Our IF analysis of normal HDFs revealed decreased fibronectin ECM deposition indicating certain level of GEN action specificity.

In conclusion, our results indicate that genistein does not impair conversion of normal dermal fibroblasts to myofibroblast-like cells. Accordingly, further research using an experimental animal as in vivo model is warranted by present set of in vitro data.

\section{Conflict of Interest}

There is no conflict of interest.

\section{Acknowledgements}

This study was supported in part by project „Centre for Tumour Ecology - Research of the Cancer Microenvironment Supporting Cancer Growth and Spread“ (No. CZ.02.1.01/0.0/0.0/16_019/0000785) supported by the Operational Programme "Research, Development and Education", by Charles University in Prague (PROGRES Q28 and Q37), by the Slovak Research and Development Agency under the contracts No. APVV-16-0207, and Medical University Science Park in Košice (MediPark, Košice - Phase II) ITMS2014+ 313011D103 supported by the Operational Programme "Research and Innovations", funded by the ERDF. Authors are grateful to Šarka Takáčová for the revision of English.

\section{Abbreviations}

ER - estrogen receptor, GEN - genistein; HDFs - human dermal fibroblasts, IL - interleukin, MAPK - mitogen activated protein kinases, MLCK - myosin light-chain kinase, ROCK - Rho GTPase, $\alpha$-SMA - alpha smooth muscle actin, TGF- $\beta 1$ - transforming growth factor beta 1 .

\section{References}

ANDUGULAPATI SB, GOURISHETTI K, TIRUNAVALLI SK, SHAIKH TB, SISTLA R: Biochanin-A ameliorates pulmonary fibrosis by suppressing the TGF-beta mediated EMT, myofibroblasts differentiation and collagen deposition in in vitro and in vivo systems. Phytomedicine 78: 153298, 2020. https://doi.org/10.1016/j.phymed.2020.153298

ASHCROFT GS, DODSWORTH J, VAN BOXTEL E, TARNUZZER RW, HORAN MA, SCHULTZ GS, FERGUSON MW: Estrogen accelerates cutaneous wound healing associated with an increase in TGF-betal levels. Nat Med 3: 1209-1215, 1997. https://doi.org/10.1038/nm1197-1209

BERMAN B, MADERAL A, RAPHAEL B: Keloids and hypertrophic scars: Pathophysiology, classification, and treatment. Dermatol Surg 43 (Suppl 1): S3-S18, 2017. https://doi.org/10.1097/DSS.0000000000000819

BERRY DP, HARDING KG, STANTON MR, JASANI B, EHRLICH HP: Human wound contraction: collagen organization, fibroblasts, and myofibroblasts. Plast Reconstr Surg 102: 124-131, 1998. https://doi.org/10.1097/00006534-199807000-00019

BRENMOEHL J, MILLER SN, HOFMANN C, VOGL D, FALK W, SCHÖLMERICH J, ROGLER G: Transforming growth factor-beta 1 induces intestinal myofibroblast differentiation and modulates their migration. World J Gastroenterol 15: 1431-1442, 2009. https://doi.org/10.3748/wjg.15.1431

CAO C, LI S, DAI X, CHEN Y, FENG Z, ZHAO Y, WU J: Genistein inhibits proliferation and functions of hypertrophic scar fibroblasts. Burns 35: 89-97, 2009. https://doi.org/10.1016/j.burns.2008.03.011

CANNITO S, NOVO E, PAROLA M: Therapeutic pro-fibrogenic signaling pathways in fibroblasts. Adv Drug Deliv Rev 121: 57-84, 2017. https://doi.org/10.1016/j.addr.2017.05.017

CAO C, LI SR, DAI X, CHEN YQ, FENG Z, QIN X, ZHAO Y, WU J: The effects of genistein on tyrosine protein kinase-mitogen activated protein kinase signal transduction pathway in hypertrophic scar fibroblasts. (Article in Chinese) Zhonghua Shao Shang Za Zhi 24: 118-121, 2008.

DERYNCK R, ZHANG YE: Smad-dependent and Smad-independent pathways in TGF-beta family signalling. Nature 425: 577-584, 2003. https://doi.org/10.1038/nature02006 
DIEL P, OLFF S, SCHMIDT S, MICHNA H: Molecular identification of potential selective estrogen receptor modulator (SERM) like properties of phytoestrogens in the human breast cancer cell line MCF-7. Planta Medica 67: 510-514, 2001. https://doi.org/10.1055/s-2001-16474

DVORANKOVA B, LACINA L, SMETANA K JR: Isolation of normal fibroblasts and their cancer-associated counterparts (CAFs) for biomedical research. Methods Mol Biol 1879: 393-406, 2019. https://doi.org/10.1007/7651_2018_137

EMMERSON E, CAMPBELL L, ASHCROFT GS, HARDMAN MJ: The phytoestrogen genistein promotes wound healing by multiple independent mechanisms. Mol Cell Endocrinol 321: 184-193, 2010. https://doi.org/10.1016/j.mce.2010.02.026

HERICHOVA I, REIS R, HASAKOVA K, VICIAN M, ZEMAN M: Sex-dependent regulation of estrogen receptor beta in human colorectal cancer tissue and its relationship with clock genes and VEGF-A expression. Physiol Res 68 (Suppl 3): S297-S305, 2019. https://doi.org/10.33549/physiolres.934352

HERICHOVA I, REIS R, HASAKOVA K, VICIAN M: Downregulation of miR-30c-5p expression in colorectal cancer tissue is sex-dependent. Physiol Res 69 (Suppl 3): S479-S487, 2020. https://doi.org/10.33549/physiolres.934598

HILL M, TříSKALA Z, HONCŮ P, KREJČÍ M, KAJZAR J, BIČÍKOVÁ M, ONDŘEJÍKOVÁ L, JANDOVÁ D, STERZL I: Aging, hormones and receptors. Physiol Res 69 (Suppl 2): S255-S272, 2020. https://doi.org/10.33549/physiolres.934523

JURZAK M, ADAMCZYK K, ANTONCZAK P, GARNCARCZYK A, KUŚMIERZ D, LATOCHA M: Evaluation of genistein ability to modulate CTGF $\mathrm{mRNA}$ /protein expression, genes expression of TGFbeta isoforms and expression of selected genes regulating cell cycle in keloid fibroblasts in vitro. Acta Pol Pharm 71: 972-986, 2014.

KLASS BR, GROBBELAAR AO, ROLFE KJ: Transforming growth factor beta1 signalling, wound healing and repair: a multifunctional cytokine with clinical implications for wound repair, a delicate balance. Postgrad Med J 85: 9-14, 2009. https://doi.org/10.1136/pgmj.2008.069831

LICHTMAN MK, OTERO-VINAS M, FALANGA V: Transforming growth factor beta (TGF-beta) isoforms in wound healing and fibrosis. Wound Repair Regen 24: 215-222, 2016. https://doi.org/10.1111/wrr.12398

MARINI H, POLITO F, ALTAVILlA D, IRRERA N, MINUTOLI L, CALÒ M, ADAMO EB, VACCARO M, SQUADRITO F, BITTO A: Genistein aglycone improves skin repair in an incisional model of wound healing: a comparison with raloxifene and oestradiol in ovariectomized rats. Br J Pharmacol 160: 1185-1194, 2010. https://doi.org/10.1111/j.1476-5381.2010.00758.x

MATSUDA T, YAMAMOTO T, MURAGUCHI A, SAATCIOGLU F: Cross-talk between transforming growth factorbeta and estrogen receptor signaling through Smad3. J Biol Chem 276: 42908-42914, 2001. https://doi.org/10.1074/jbc.M105316200

NING Y, CHEN J, SHI Y, SONG N, YU X, FANG Y, DING X: Genistein ameliorates renal fibrosis through regulation snail via m6A RNA demethylase ALKBH5. Front Pharmacol 11: 579265, 2020. https://doi.org/10.3389/fphar.2020.579265

PAKSHIR P, NOSKOVICOVA N, LODYGA M, SON DO, SCHUSTER R, GOODWIN A, KARVONEN H, HINZ B: The myofibroblast at a glance. J Cell Sci 133: jcs227900, 2020. https://doi.org/10.1242/jcs.227900

SHI X, YOUNG CD, ZHOU H, WANG X: Transforming growth factor-beta signaling in fibrotic diseases and cancerassociated fibroblasts. Biomolecules 10: 1666, 2020. https://doi.org/10.3390/biom10121666

YUAN WJ, JIA FY MENG JZ: Effects of genistein on secretion of extracellular matrix components and transforming growth factor beta in high-glucose-cultured rat mesangial cells. J Artif Organs 12: 242-246, 2009. https://doi.org/10.1007/s10047-009-0479-y 